\title{
Efficiency of particle retention and filtration rate in 6 species of Northeast American bivalves
}

\author{
Hans Ulrik Riisgård \\ Institute of Biology, Odense University, Campusvej 55, DK-5230 Odense M, Denmark
}

\begin{abstract}
Particle retention efficiency in 6 species of suspension-feeding Northeast American bivalves was determined by simultaneous measurement of clearance of different sized particles. Geukensia demissa, Spisula solidissima, Brachidontes exustus, and Mercenaria mercenaria, which all possess large laterofrontal cirri, completely retained particles above $4 \mu \mathrm{m}$. Below this the retention efficiency gradually decreased to between 35 and $70 \%$ for $2 \mu \mathrm{m}$ particles. Crassostrea virginica, which has small laterofrontal cirri, and Argopecten irradians, which has none, entirely retained particles above 5 to $6 \mu \mathrm{m}$. Below $5 \mu \mathrm{m}$ the retention efficiency gradually decreased to $50 \%$ for $2 \mu \mathrm{m}$ particles in $\mathrm{C}$. virginica while it sharply dropped to $15 \%$ for $2 \mu \mathrm{m}$ particles in A. irradians. At 27 to $29^{\circ} \mathrm{C}$ filtration rates $\left(F, l \mathrm{~h}^{-1}\right)$ as a function of tissue dry weight $(W, g)$ could be described by the allometric equation: $F=$ $a W^{b}$. In $C$. virginica, $G$. demissa and $M$. mercenaria the equations were: $6.79 W^{0.73}, 6.15 W^{083}$ and $1.24 W^{0.80}$, respectively. $B$. exustus and $S$. solidissima showed intermediary filtration rates. In $G$. demissa gill area increased with size at the same rate as filtration rate.
\end{abstract}

\section{INTRODUCTION}

In the intertidal zone of salt marshes, hard clams, oysters and ribbed mussels are important animals in the flow of energy and nutrients (Kuenzler 1961a,b, Jordan \& Valiela 1982). Furthermore, oysters, clams and scallops are commercially important, and aquaculture of these shellfish is a rapidly growing industry. When dealing with energy or nutrient budgets of suspension-feeding bivalves, the ingestion rate is of significant interest. The amount of food consumed by suspension-feeding bivalves is determined by the filtration rate and efficiency of particle retention by the gill which has evolved to act as both a water-transporting and a particle-retaining organ.

The bivalve gill consists of parallel oriented filaments possessing ciliary tracts. In addition to water-pumping lateral ciliary tracts and particle-transporting frontal ciliary tracts, the gill filaments passess laterofrontal ciliary tracts which may be composed of 2 types of ciliary structure: laterofrontal cirri and prolaterofrontal cilia (Owen \& McCrae 1976). The laterofrontal cirri are widely thought to act as filters and to retain particles from the water passing through the gill (Silvester \& Sleigh 1984).

Since the type of the laterofrontal tracts as well as the length of the laterofrontal cirri are suggested to be of particular significance in the retention of palicies, a comparative study of particle retention in bivalves with large, small and non-existent laterofrontal cirri forms part of the present study on filtration rates in 6 Northeast American bivalves.

\section{MATERIALS AND METHODS}

The experimental work was carried out at the Skidaway Institute of Oceanography, Georgia, USA, during July and August 1987.

Atlantic ribbed mussels Geukensia demissa (L.) and American oysters Crassostrea virginica (Gmelin) were collected from the intertidal zone in the vicinity of the institute. Northern quahogs (hard clam) Mercenaria mercenaria (L.) and scorched mussels Brachidontes exustus (L.) were collected at low tide in the salt marshes of the Wassaw Sound, an estuarine embayment in the Georgia Bight. Bay scallops Argopecten irradians (L.) came from St Joseph's Bay, Florida, USA. Atlantic surf clams Spisula solidissima (Dillwyn) originally came from National Marine Fisheries Services, Milford Laboratory, Connecticut, USA in 1986 and were planted in the salt marshes of the Wassaw Sound. In 
May 1987 surf clams were harvested and held at $23^{\circ} \mathrm{C}$ in the laboratory during the summer. Before the experiments the clams were acclimated to $28^{\circ} \mathrm{C}$ for $1 \mathrm{wk}$.

Particles used for measuring retention efficiency consisted of bacteria and small particles (2 to $3 \mu \mathrm{m}$ ) occuring in the hatchery seawater system. In addition to these particles, cultivated unicellular algae Isochrysis galbana ( 3 to $4 \mu \mathrm{m}$ ) and Cryptomonas sp. (ca 5 to $9 \mu \mathrm{m}$ ) were added in the experiments. These algae were chosen for their nearly spherical shape to assure reliable measurements of their diameter with the electronic particle counter. The concentration of particles was determined with a Coulter Counter, Model TAII, with a population accessory plotter and a 100 um aperture tube. Algal concentrations used in the experiments never gave rise to production of pseudofeces.

The volume of water cleared of particles per unit time (clearance $=F_{1} \backslash \mathrm{h}^{-1}$ ), of different sized particles was estimated by measuring the exponential reduction of particles in glass beakers with a known volume of water $(V, 1)$ using the formula: $F=V / t \times \ln C_{0} / C_{t}$ where $t$ is the time in $h$ and $C_{0}$ and $C_{t}$ are the particle concentrations at times 0 and $t$. This indirect clearance method' agrees well with other both indirect and direct methods used for measuring filtration rates in mussels (Famme et al. 1986). Clearance measurements were performed in volumes of 0.2 to 2 i seawater depending on the size of the bivalves. Approximate mixing was ensured by aeration of the suspension. Samples ( $25 \mathrm{ml}$ ) for particle analysis were taken by a pipette every 10 to $15 \mathrm{~min}$. The decrease in particle concentration was followed until 40 to $50 \%$ of the 5 to $9 \mu \mathrm{m}$ particles were removed. To eliminate error caused by bacterial growth during the experiment, the experimental time was kept below 60 min.

About $1 \mathrm{~h}$ prior to an experiment algae were added to grazing vessels to stimulate the bivalves to fully open their valves and to extend their siphons and mantle edges. Bivalves judged not fully open (i.e. disturbed) were not used.

An increase in the concentration of 2 to $3 \mu \mathrm{m}$ particles was frequently observed during retention efficiency experiments giving rise to 'negative retention' of the small particles. As the particles (of unknown composition) must have been produced by the bivalves these samples were neglected. The same phenomenon was also noticed by Vahl (1972) and Mohlenberg \& Riisgård (1978).

The spectrum of particle retention was found by expressing the clearance of the different sized particles relative to the mean of the 2 highest clearance rates measured. The filtration rate was estimated as the mean clearance rate of $100 \%$ efficiently retained particles.

Gill areas of Geukensia demissa were determined by placing specimens with one valve removed under a
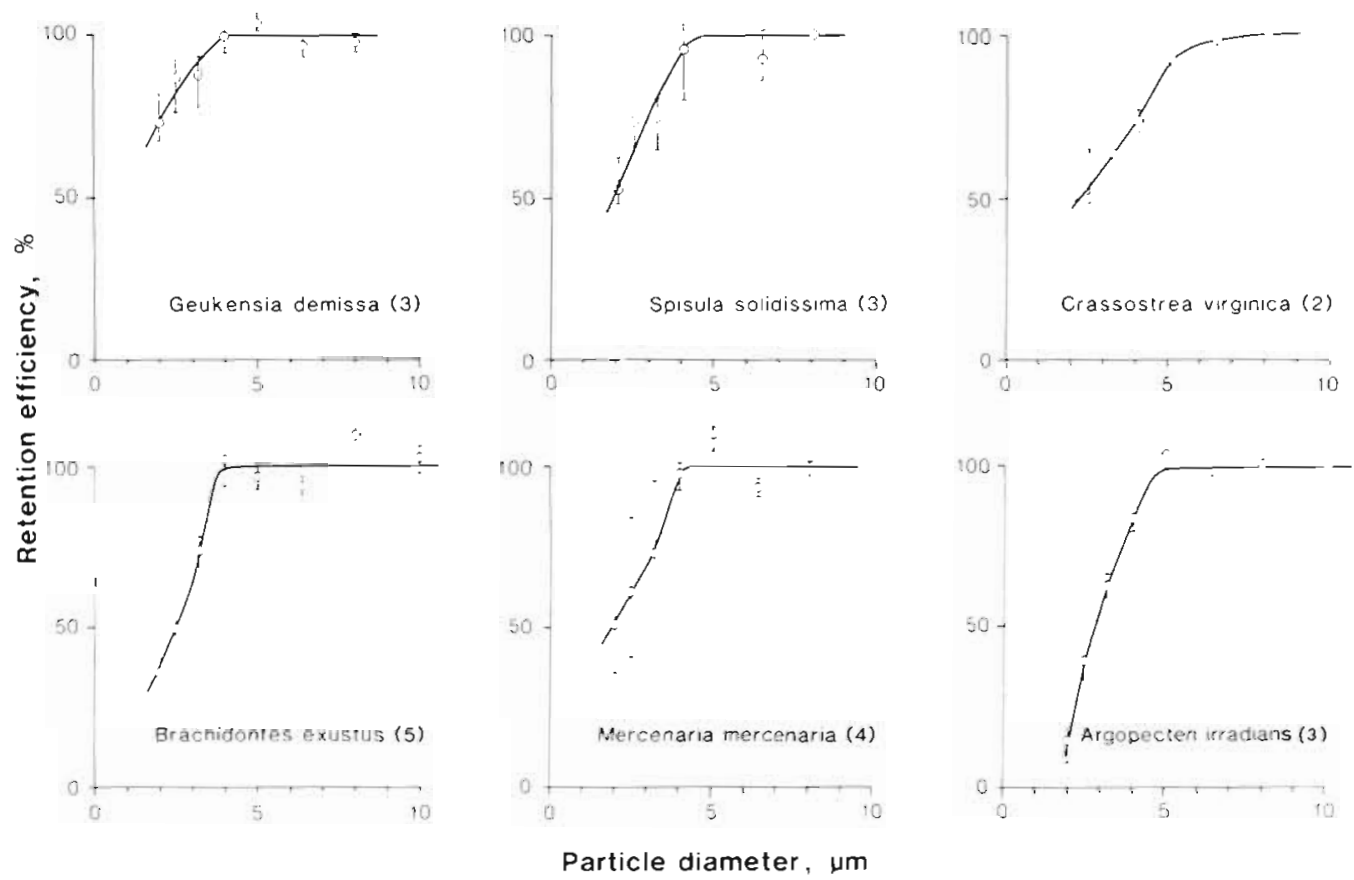

Fig. 1. Particle retention efficiency as a function of particle diameter in 6 species of bivalves. Each value is the mean and range of one measurement on each of 2 to 5 indivduals as indicated by the figures in parentheses 
Fig. 2. Filtration rate as a function of dry weight of tissues in 6 species of bivalves. Regression lines are shown for Crassostrea virginica (A), Geukensia demissa (B) and Mercenaria mercenaria (C). (\$) Argopecten irradians; (0) Spisula solidissima; (•) Brachidontes exustus

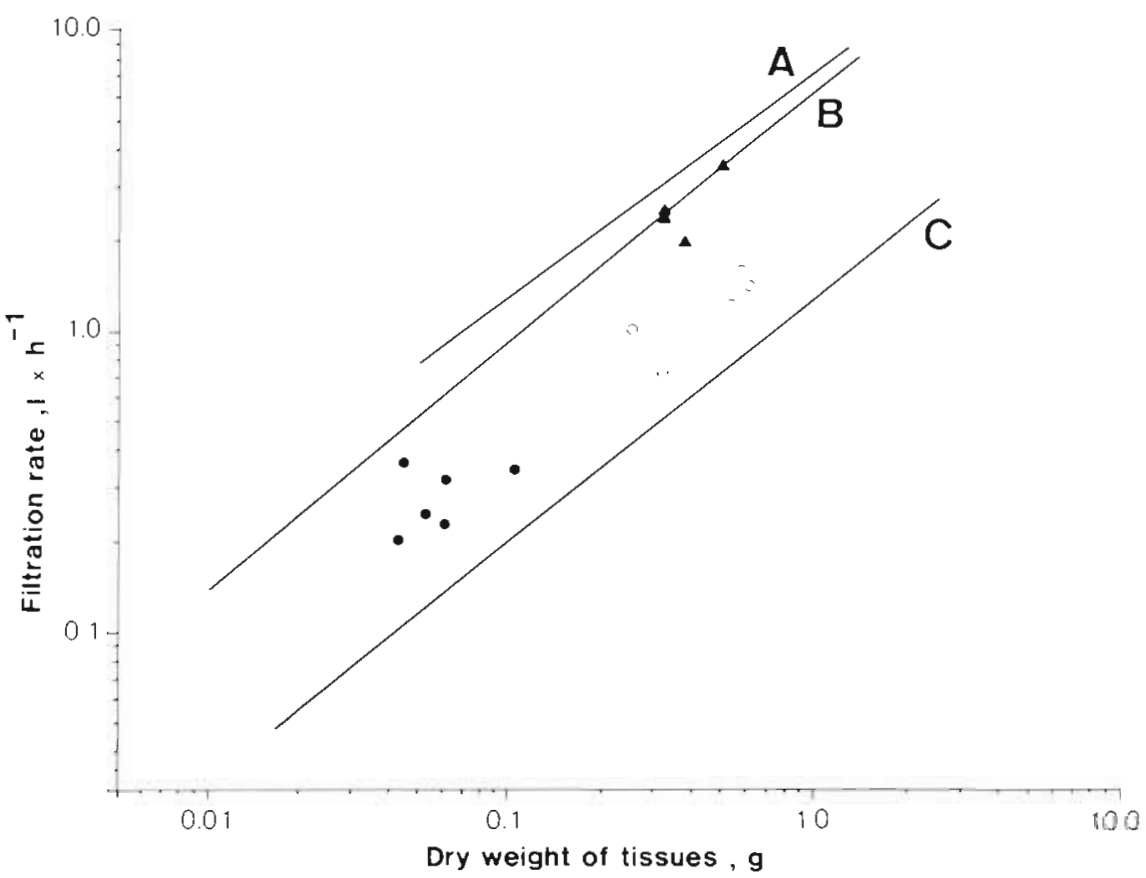

dropped off and approached $15 \%$ for $2 \mu \mathrm{m}$ particles.

The filtration rate $\left(F, \mathrm{lh}^{-1}\right)$ in Crassostrea virginica, Geukensia demissa and Mercenaria mercenaria (Fig. 2) increased with increasing dry weight of the soft parts $(W, g)$ according to the equation. $F=a W^{b}$ (Table 1$)$. The highest filtration rates were found in $C$. virginica $\left(a=6.80 \mathrm{l} \mathrm{h}^{-1}\right)$, the lowest in $M$. mercenaria $(a=1.24$ i $^{-1}$ ). Filtration rates in $G$. demissa and Argopecten irradians were about equal and close to those measured for C. virginica while Brachidontes exustus and Spisula solidissima showed intermediary filtration rates. The $b$-values varied between $0.73 \pm 0.22 \mathrm{in}$ Crassostrea virginica and $0.83 \pm 0.07$ in Geukensia demissa. An analysis of covariance accepted a hypothesis of equal slopes, but not of equal intercepts (M. mercenaria has a significantly lower intercept than $G$. demissa and $C$. virginica).

In Geukensia demissa the b-value for the regression of filtration rate on dry weight can be compared to the exponent $0.78 \pm 0.08$ of the gill area, expressed as a function of dry weight (Table 1). Filtration rate thus appears to be directly correlated to gill area.

Table 1. Regression constants of filtration rate $\left(F, l \mathrm{~h}^{-1}\right)$ and gill area $\left(\mathrm{G}, \mathrm{cm}^{2}\right)$ on dry weight of tissues (W, $\left.\mathrm{g}\right)$ in 3 species of bivalves. Regression equations: $F$ or $G=a W^{b} n$ : number of individuals; $r$; correlation coefficient; SE: standard error

\begin{tabular}{llrrrrr|}
\hline Species & Regression & $n$ & $W$ & $a \pm$ SE & $b \pm$ SE & $r$ \\
\hline Crassostrea virginica & $F$ on $W$ & 10 & $0.063-0.994$ & $6.79 \pm 1.41$ & $0.73 \pm 0.22$ & 0.76 \\
Geukensia demissa & $F$ on $W$ & 18 & $0.009-1.039$ & $6.15 \pm 1.19$ & $0.83 \pm 0.07$ & 0.95 \\
Mercenaria mercenaria & $F$ on $W$ & 6 & $0.017-2.387$ & $1.24 \pm 1.21$ & $0.80 \pm 0.09$ & 0.98 \\
Geukensia demissa & Gon $W$ & 9 & $0.116-0.857$ & $49.97 \pm 1.11$ & $0.78 \pm 0.08$ & 0.97 \\
\hline
\end{tabular}




\section{DISCUSSION}

Patterns of retention efficiency in bivalves found in this work are very similar to the findings of Mohlenberg \& Riisgård (1978) in 13 species of suspensionfeeding Northwest European bivalves. Thus, particles above $4 \mu \mathrm{m}$ are completely retained in bivalves that possess large laterofrontal cirri (i.e. Geukensia demissa, Spisula solidissima, Brachidontes exustus and Mercenaria mercenaria) whereas only particles larger than 5 to $6 \mu \mathrm{m}$ are entirely retained in Crassostrea virginica, which has small laterofrontal cirri, and in Argopecten irradians, which has no laterofrontal cirri, but only prolaterofrontal cilia (Owen \& McCrae 1976). Also Monia squama, which lacks cirri altogether, fits into this pattern (Jørgensen et al. 1984).

The role of laterofrontal cirri in the filtering process is a subject of controversy. The filter-like meshwork of the laterofrontal cirri has given rise to the theory that they act as a mechanical filter with mesh sizes determined by the distance between the cilia branching off from the cirral shafts (Moore 1971, Silvester \& Sleigh 1984). Owen \& McCrae (1976) suggested that bivalves in which the laterofrontal ciliary tracts consist of both compound laterofrontal cirri and prolaterofrontal cilia retain particles primarily by the straining effect of the compound cirri', while bivalves without laterofrontal cirri mainly collect particles 'by way of water currents associated with the gill surface'. The 'filter theory' has been questioned by Jørgensen (1983) and Jørgensen et al. (1986) who suggested that the laterofrontal cirri do not act as sieves, but as modulators in a fluid mechanical process of particle retention.

In a comparative filtration study of gill function in Geukensia demissa, Mytilus edulis and Mya arenaria, Wright et al. (1982) found that only $G$. demissa demonstrated significant clearance $(42 \%)$ of natural bacterioplankton $(0.2$ to $2 \mu \mathrm{m})$ relative to phytoplankton $(>2 \mu \mathrm{m})$. Light microscopical measurements of the laterofrontal cirri in $G$. demissa and $M$. edulis showed that the cilia branching from cirral shafts were spaced more closely in $G$. demissa. Furthermore, cirri were more closely spaced and opposite rows of cirri were closer together in $G$. demissa. Filter mesh sizes were proposed to be $0.25 \mu \mathrm{m}$ for $G$. demissa and $1 \mu \mathrm{m}$ for $M$. edulis. According to the 'filter theory', the size threshold for particles $100 \%$ retained should be lower in $G$. demissa than in $M$. edulis, and considerably lower than $4 \mu \mathrm{m}$. This is inconsistent with the present findings for $G$. demissa which show a retention efficiency pattern very similar to $M$. edulis (Jørgensen 1975. Møhlenberg \& Riisgård 1978, Riisgård et al, 1980). In both species 4 um particles are efficiently retained while 2 um particles are retained with about $70 \%$ efficiency. The best explanation for this discrepancy may lie in the apparently low clearance rates recorded by Wright et al. (1982). Clearance rate of phytoplankton by $G$. demissa measured by Wright et al. was only 1.1 $1 \mathrm{~h}^{-1} \mathrm{~g}^{-1}$ dry weight of tissue, which is about 5 to 6 times lower than the rates found in the present work, and the clearance rate by $M$. edulis was about 30 times lower than measured by Møhlenberg \& Riisgård (1979).

Future investigations of the role of the laterofrontal ciliary tracts should consider the apparently disregarded fact that bivalves with gills lacking large laterofrontal cirri are able to completely retain 5 to 6 um particles. It remains to be clarified how these relatively small particles are retained from the through current by a gill which obviously lacks a mechanical cirri filter.

Paimer \& Williams (1980) suggested that retention efficiency in Argopecten irradians and Crassostrea virginica may be adjusted in response to low or high algal concentrations. The great consistency in retention efficiency found in 13 bivalve species by Mohlenberg \& Riisgård (1978), as well as the consistency in the present work (Fig. 1), indicates that the bivalves studied probably do not change their retention efficiency in response to particle concentrations.

The filtration rates measured at 27 to $29^{\circ} \mathrm{C}$ in the present work (Fig. 2) are close to, and generally not higher, than filtration rates measured at 10 to $13^{\circ} \mathrm{C}$ in 13 species of Northwest European bivalves (Møhlenberg \& Riisgård 1979). Such adaptation of filtration rates to temperature was also found between populations of Mytilus californianus from various localities along the west coast of the USA, ranging from Friday Harbour to Los Angeles (Rao 1953). Bivalves adapted to high temperatures thus appear to maintain about the same filtration rates as bivalves adapted to relatively low temperatures. This temperature adaptation extends to other rate functions, particular the metabolic rate (Thorsen 1936, 1952, Bullock 1955). Presumably, dependency of filtration (feeding) rate and metabolic rate on temperature is integrated with other bioenergetic parameters, maintaining the potential for growth relatively independent of latitude (Mytilus edulis in Alaska [Paul et al. 1978] and California [Reish 1964]).

Slopes of regression lines for filtration rates found in this study ( $b$-values between 0.73 and 0.83 ; Table 1 ) agree with those of Møhlenberg \& Riisgård (1978), most of the authors listed by Winter (1978), Risgård \& Møhlenberg (1979) and Gerdes (1983).

Recalculation of the data obtained by Rice \& Smith (1958) on Mercenaria mercenaria shows that the clearance rate $\left(\mathrm{C}, \mathrm{I} \mathrm{h}^{-1}\right.$ ) for Nannochloris (2 $\mathrm{\mu m}$ ) as a function of wet weight of soft parts $(W, g)$ can be expressed by the equation. $C=0.535 W^{0.305}(r=0.966)$. To enable comparison with the present work to be made, the 
filtration rate $\left(F, \mathrm{~h} \mathrm{~h}^{-1}\right)$ as a function of wet weight of soft parts $(W, g)$ was calculated: $F=0.341 W^{0.777}(r=$ 0.960 ). The small exponent of 0.305 found by Rice \& Smith may indicate that clearance rates of the larger clams were underestimated. It is difficult to avoid disturbance to organisms and to keep clams, particularly large ones, fully open in the laboratory. In the present work about $30 \%$ of the filtration measurements on $M$. mercenaria were discarded as the clams were judged not to be fully open during the entire experimental period.

The filtration rate in Mercenaria mercenaria was measured by Coughlan \& Ansell (1964) by a 'direct' method which allowed measurements on clams naturally buried in sediment. The relation between filtration rate and dry flesh weight $\left(18\right.$ to $20^{\circ} \mathrm{C}$ ) was twice that measured in this study on clams outside their substratum. Possible reduced filtration rates measured in the present work due to suboptimal conditions cannot therefore be excluded.

Filtration rates in relation to body size of Mercenaria mercenaria have been studied in through-flow systems by Walne (1972). The slope of the regression line expressing the weight-specific filtration rate in relation to body size was found to be -0.82 , the $b$-value relating filtration rate of the dry weight of flesh thus being 0.18 . This $b$-value is 3 to 4 times lower than expected. A possible explanation may be the flow rates used by Walne which were generally lower than the rates at which the clearance rates approximate filtration rates (Riisgard 1977). The relationship between filtration ldie and shell length of $M$. mercenaria was determined at different temperatures by Hibbert (1977) in a flowthrough system. A mean exponent of 0.892 was found for equations relating filtration rate to shell length. This exponent is remarkably small because the gill area, and thus the filtration rate, may be expected to be directly proportional to the square of shell length. In the present work the following relation between filtration rate $\left(F, \mathrm{lh}^{-1}\right)$ and shell length $(L, \mathrm{~mm})$ of $M$. mercenaria was found: $F=2.4 \times 10^{-4} L^{2.19}(r=0.960)$, whereas the relation between gill area $\left(G, \mathrm{~cm}^{2}\right)$ and shell length $(L, \mathrm{~mm})$ in Geukensia demissa was: $G=$ $8.4 \times 10^{-3} L^{1.91}(r=0.988)$. In both cases the exponents are close to 2 . The filtration rates at $25^{\circ} \mathrm{C}$ of 50 to $60 \mathrm{~mm}$ hard clams found by Hibbert are close to the present findings, but the filtration rates of larger clams seem to have been underestimated, probably due to insufficient through-flow and subsequent recirculation of water already once filtered (Hildreth \& Crisp 1976 , Riisgård 1977).

Regression equations for filtration rates $\left(F, \mathrm{l} \mathrm{h}^{-1}\right)$ vs dry flesh weight $(W, g)$ of Geukensia demissa in a New England salt marsh were determined by Jordan \& Valiela (1982) using the clearance method. In summer the regression equation was: $F=3.48 W^{0.385}(r=$ $0.640)$, and in fall it was: $F=1.41 W^{0.404}(r=0.409)$. The summer measurements agree with filtration rates measured by Kuenzler (1961b), but the rate of a $1 \mathrm{~g}$ mussel was nearly two times lower than that found in the present study. Further, the $b$-values of 0.385 and 0.404 appear low; the latter, according to the authors, was not significantly different from zero. Thus, the mussels appear not to have exploited their filtration capacities in those experiments.

Many earlier filtration rate determinations on Crassostrea virginica were performed by direct methods where the exhaled water was separated from the surrounding water (e.g. by means of a rubber apron), collected, and measured. Results of earlier work on rates of water transport in $C$. virginica and other bivalves have been summarized by Jørgensen (1966). More recently, filtration rates in $C$. virginica were measured by the so-called 'constant-level tank' technique (Bernard 1973). The very low pumping rate (41 $\mathrm{ml} \mathrm{h}^{-1} \mathrm{~g}^{-1}$ ) measured shows that the technique used probably did not estimate the true filtration rate of the oyster. The same drawback applies to most other pumping rates determined by direct techniques. The reasons for this are mechanical disturbance of the animals and a build up of hydrostatic pressure which drastically reduces water pumping in bivalves (Famme et al. 1986, Jørgensen et al. 1986).

Filtration rates in Crassostrea virginica were measured by an indirect technique by Langefoss \& Maurer (1975). The iiltration rate was tound to be reduced at high algal concentrations $\left(5 \times 10^{5}\right.$ to $10^{6}$ Phaeodactylum cells $\mathrm{ml}^{-1}$ ). At a more natural algal concentration of $2.5 \times 10^{4}$ cells $\mathrm{ml}^{-1}$ the maximum filtration rate of oysters with a mean tissue dry weight of $0.211 \mathrm{~g}$ was $1.85 \mathrm{I}$ $\mathrm{h}^{-1}$ at $20^{\circ} \mathrm{C}$. Oysters of the same size filtered $2.18 \mathrm{l} \mathrm{g}^{-1}$ in the present work.

By measuring the clearance of radioactive labelled plankton, Chipman \& Hopkins (1954) estimated the average filtration rate of Pecten (= Argopecten) irradians ( 38 to $44 \mathrm{~mm}$ shell length) to be $3.26 \mathrm{l} \mathrm{h}^{-1}$. This value is close to $3.40 \mathrm{l} \mathrm{h}^{-1}$ obtained for $A$. irradians (34.4 to $40.7 \mathrm{~mm}$ ) in this study.

The high sensitivity of bivalves to disturbance and laboratory conditions seems to have influenced the filtration rates in several of the studies cited in this paper. As only bivalves judged to be fully open were used in the present work the measured filtration rates are probably close to the filtration capacities of the bivalves. To what degree the filtration capacities are exploited in nature remains to be assessed. It should be emphasized, however, that Mytilus edulis must be maximally open and continuously filtering to get food enough to obtain the net growth efficiencies recorded in nature where the algal biomass generally is below 
1 mg dry wt l ${ }^{-1}$ (Kiørboe et al. 1981, Riisgărd \& Poulsen 1981, Riisgard \& Randløv 1981). Further, it has recently been shown that the capacity of the bivalve pump can be exploited only in undisturbed bivalves, and that the pump potential presumably constitutes an evolutionary adaptation to the prevailing food concentrations in the environment (Jørgensen et al. 1988). Therefore, the filtration rate capacities measured in the present work may be regarded as estimates of normal pumping rates in undisturbed natural bivalves.

Acknowledgements. I am grateful to Dr G.-A. Paffenhöfer, Dr P. Hefferman and Mr R. L. Waker at the Skidaway Institute of Oceanography for provision of facilities, supplying algae cultures and bivalves, and for help in other ways. Thanks are due to Dr C. Barker Jorgensen and Mr S. M. Gallager for critically reading the manuscript. This work has been supported by a grant from the Danish Natural Science Research Council (M 11-6385).

\section{LITERATURE CITED}

Bernard, F. R. (1973). Annual biodeposition and gross energy budget of mature Pacific oysters, Crassostrea gigas. J. Fish. Res. Bd Can. 31: 185-190

Bullock, T. H. (1955). Compensation for temperature in the metabolism and activity of poikilotherms. Biol. Rev. 30 : $311-342$

Chipman, W. A., Hopkins, J. G. (1954). Water filtration by the bay scallop, Pecten irradians, as observed with the use of radioactive algae. Biol. Bull. mar. biol. Lab., Woods Hole 107: $80-91$

Coughlan, J., Ansell, A. D. (1964). A direct method for determining the pumping rate of siphonate bivalves. J. cons. int. Explor. Mer 29: 205-213

Famme, P., Riisgård, H. U., Jørgensen, C. B. (1986). On direct measurement of pumping rates in the mussel Mytilus edulis. Mar Biol. 92: 323-327

Gerdes, D. (1983). The Pacific oyster Crassostrea gigas. Part I Feeding behaviour of larvae and adults. Aquaculture 31 195-219

Hibbert, C. J. (1977). Energy relations of the bivalve Mercenaria mercenaria on an intertidal mudflat. Mar. Biol 44: 77-84

Hildreth, D. I., Crisp, D. J (1976). A corrected formula for calculation of filtration rate of bivalve molluscs in experimental flowing systems. J. mar. biol. Ass. U. K. 56: 111-120

Jordan, T. E., Valiela, I. (1982). A nitrogen budget of the ribbed mussel, Geukensia demissa, and its significance in a nitrogen flow in a New England salt marsh. Limnol. Oceanogr $27 \cdot 75-90$

Jørgensen, C. B. (1.966). Biology of suspension feeding. Pergamon Press, Oxford

Jørgensen, C. B. (1975). On gill function in the mussel, Mytilus edulis L. Ophelia 13: 187-232

Jørgensen, C. B. (1983\}. Fluid mechanical aspects of suspension feeding. Mar. Ecol. Prog. Ser 11: 89-103

Jørgensen, C. B., Kiørboe, T., Møhlenberg, F., Riisgård, H. U, (1984). Ciliary and mucus-net filter feeding, with special reference to fluid mechanical characteristics. Mar Ecol. Prog. Ser. 15: 283-292

Jorgensen, C. B., Famme, P., Saustrup Kristensen, H., Larsen, P. S., Mohlenberg, F., Riisgård, H. U. (1986). The bivalve pump. Mar. Ecol. Prog. Ser 34: 69-77
Jørgensen, C. B., Larsen, P. S., Møhlenberg, F, Riisgård, H. U. (1988). The mussel pump: properties and modelling. Mar. Ecol. Prog. Ser. 45: 205-216

Kiorboe, T., Møhlenberg, F., Nøhr, O. (1981). Effect of suspended bottom material on growth and energetics in Mytilus edulis. Mar. Biol. 61 283-288

Kuenzler. E. J. (1961a). Phosphorus budget of a mussel population. Limnol Oceanogr. 6: 400-415

Kuenzler, E. J. (1961b). Structure and energy flow of a mussel population in a Georgia salt marsh. Limnol. Oceanogr 6: 191-204

Langefoss, C. M., Maurer, D. (1975). Energy partioning in the American oyster, Crassostrea virginica (Gmelin). Proc. natl Shellfish. Ass. 65: 20-25

Moore, H. J. (1971). The structure of the latero-frontal cirri on the gills of certain lamelibranch molluscs and their role in suspension feeding. Mar. Biol. 11: 23-27

Møhlenberg. F., Riisgård, H. U. (1978). Efficiency of particle retention in 13 species of suspension feeding bivalves. Ophelia 17: 239-246

Møhlenberg, F., Riisgård, H. U. (1979). Filtration rate, using a new indirect technique, in thirteen species of suspensionfeeding bivalves. Mar. Biol. 54: 143-148

Owen, G., McCrae, J. M. (1976). Further studies on the laterofrontal tracts of bivalves. Proc. R. Soc. Lond. 194: 527-544

Palmer, R. E., Williams, L. G. (1980). Effect of particle concentration on filtration efficiency of the bay scallop Argopecten irradians and the oyster Crassostrea virginica. Ophelia 19: $163-174$

Paul, A. J., Paul, J. M., Neve, R. A. (1978). Phytoplankton densities and growth of Mytilus edulis in an Alaskan artificial upwelling system. J. cons. int. Explor. Mer 38: $100-104$

Rao, K. P. (1953). Rate of water propulsion in Mytilus californianus. Biol. Bull. mar. biol. Lab. Woods Hole 104: 171-181

Reish, D. J. (1964). Studies on Mytilus edulis community in Alarmitos Bay, California: I. Development and destruction of the community. Veliger 6: 124-131

Rice, T. R., Smith, R. J. (1958). Filtering rates of the hard clam (Venus mercenaria) determined with radioactive plankton. Fish. Bull. U. S. 58 (129): 73-82

Riisgård, H. U. (1977). On measurements of the filtration rates of suspension feeding bivalves in a flow system. Ophelia 16: $167-173$

Riisgård, H. U., Møhlenberg, F. (1979). An improved automatic apparatus for determining the filtration rate of Mytilus edulis as a function of size and algal concentration. Mar. Biol. 52: 61-67

Riisgård, H. U., Randløv, A., Sand Kristensen, P. (1980). Rates of water processing, oxygen consumption and efficiency of particle retention in veligers and young post-metamorphic Mytilus edulis. Ophelia 19: 37-47

Riisgård, H. U., Randløv, A. (1981). Energy budgets, growth and filtration rates in Mytilus edulis at different algal concentrations. Mar. Biol. 61: 227-234

Riisgård, H. U., Poulsen, E. (1981). Growth of Mytilus edulis in net bags transferred to different localities in a eutrophicated Danish fjord. Mar. Pollut. Bull. 12: 272-276

Silvester, N. R., Sleigh, .1. A. (1984). Hydrodynamic aspects of particle capture by Mytilus. J. mar. biol. Ass. U. K. 64: $859-879$

Thorsen, G. (1936). The larval development, growth and metabolism of Arctic marine bottom invertebrates. Meddr Granland $100(6): 1-155$

Thorsen, G. (1952). Zur jetzigen Lage der marinen BodentierOkologie. Verh. dt. zool. Ges. (Wilhelmshaven 1951) 1952: $276-327$ 
Vahl, O. (1972). Efficiency of particle retention in Mytilus edulis L. Ophelia 10: $67-74$

Walne, P. R. (1972). The influence of current speed, body size and water temperature on the filtration rate of five species of bivalves. J. mar biol. Ass. U.K. 52: 345-374

Winter, J. E. (1978). A review on the knowledge of suspension- feeding in lamellibranchiate bivalves, with special reference to artificial aquaculture systems. Aquaculture 13: 1-33 Wright, R. T., Coffin, R. B., Ersing, C. P., Pearson, D. (1982). Field and laboratory measurements of bivalve filtration of natural marine bacterioplankton. Limnol. Oceanogr. 27. 91-98

This article was submitted to the editor; it was accepted for printing on April 19, 1988 